\title{
A Practical Approach to Reduce Greenhouse Gas Emissions from Open Dumps through Infrastructure Restructuring: A Case Study in Nanjing City, China
}

\author{
Jing Ma ${ }^{1} \mathbb{D}$, Zhanbin Luo ${ }^{2}$, Fu Chen ${ }^{1,2,3, * \mathbb{D}}$, Qianlin Zhu ${ }^{1}$, Shaoliang Zhang ${ }^{2}$ (D) \\ and Gang-Jun Liu ${ }^{3}$ \\ 1 Low Carbon Energy Institute, China University of Mining and Technology, Xuzhou 221008, China; \\ jingma2013@cumt.edu.cn (J.M.); zhuq1@cumt.edu.cn (Q.Z.) \\ 2 School of Environment Science and Spatial Informatics, China University of Mining and Technology, \\ Xuzhou 221043, China; lzbin1991@cumt.edu.cn (Z.L.); slzhang@cumt.edu.cn (S.Z.) \\ 3 Geospatial Science, College of Science, Engineering and Health, RMIT University, \\ Melbourne 3000, Australia; gang-jun.liu@rmit.edu.au \\ * Correspondence: chenfu@cumt.edu.cn; Tel.: +86-5168-388-3501
}

Received: 18 July 2018; Accepted: 5 August 2018; Published: 8 August 2018

\begin{abstract}
A new environmental ban has forced the restructure of open dumps in China since 1 July 2011. A technical process was established in this study that is feasible for the upgrade of open dumps through restructuring. The feasibility of restructuring and the benefit of greenhouse gas emission reductions were assessed according to field surveys of five landfills and four dumps in Nanjing. The results showed that the daily processing capacities of the existing landfills have been unable to meet the growth of municipal solid waste (MSW), making restructuring of the landfills imperative. According to an assessment of the technical process, only four sites in Nanjing were suitable for upgrading. Restructuring the Jiaozishan landfill effectively reduced the leachate generation rate by $5.84 \%$ under its scale when expanded by $60.7 \%$ in $2015 . \mathrm{CO}_{2}$ emissions were reduced by approximately $55,000-86,000$ tons per year, in which biogas power generation replaced fossil fuels Fossil fuels accounted for the largest proportion, up to $45,000-60,000$ tons. Photovoltaic power generation on the overlying land has not only reduced $\mathrm{CO}_{2}$ emissions to $26,000-30,000$ tons per year but has also brought in continuing income from the sale of electricity. The funds are essential for developing countries such as China, which lack long-term financial support for landfill management after closure.
\end{abstract}

Keywords: municipal solid waste; landfill upgrading; leachate control; energy saving; urban management

\section{Introduction}

With increasing urbanization and economic development, municipal solid wastes (MSW) have increased on a large scale in recent years. Although all countries across the world are trying hard to reduce the emissions of MSW [1], it is frustrating that global waste will undoubtedly exceed 2.2 billion tons by 2025 [2]. The urbanization rate in China has increased rapidly within the past 30 years, and with approximately 700 million citizens, the country already has the most urban residents in the world [3]. However, the collection, disposal, and recycling of MSW cannot keep up with rapid urban development [4]. A large amount of MSW has been dumped in the areas surrounding cities, and the phenomenon of "garbage siege" is common in developing countries such as China [5-7]. Previous studies have demonstrated that this phenomenon stems from three main reasons. First, the awareness of environmental protection by urban administrators is weak. Municipal garbage 
collectors habitually throw MSW into urban fringe areas, and these wastes gradually accumulate [8]. Second, urban administrators have insufficient experience in urban governance and cannot foresee the rapid growth of the urban population. The disposal capacity is not large enough to cope with the growing MSW generation [9]. Third, some small and medium-sized cities in developing countries lack sufficient financial resources. These limited financial resources must be preferentially used for the construction of the city's most basic infrastructure and public facilities such as transportation, electricity, water supply, and so on [10]. Therefore, the phenomenon of garbage siege has gradually appeared in the surrounding cities.

There have also been many kinds of disposal methods dealing with the increasing MSW in the past few decades. Composting, biodegradation, incineration, open-air piling, and sanitary landfill are currently the primary disposal methods of MSW. However, there have been a variety of deficiencies when using these disposal technologies. For example, besides the low efficiency of composting and the high cost of biodegradation, they only dispose of organic degradable wastes [11]. Moreover, the cost of incineration is very high, and the incombustible parts and ash need to be further disposed of, which easily produces secondary pollution $[12,13]$. Sanitary landfill has been widely used in developed countries, which can simultaneously landfill organic and inorganic waste, and the cost is just $1 / 8-1 / 15$ that of incineration $[14,15]$.

There are currently more than 2000 active landfills in China, but the configuration facilities of most landfills are missing, and the pollution control effect is poor [16]. Most landfills are constructed based on open dumps, which is a common pattern in developing countries [5-7]. The congenital deficiencies of these landfills will not only lead to the decline of urban tourism and land value [17], but will also affect the urban environment. These deficiencies will negatively impact the groundwater and air and contribute to soil pollution $[12,18,19]$ as well as threaten food safety and public health $[20,21]$. Although some studies have evaluated the effects of landfills from various aspects [22-24], there has been little revealed regarding reducing greenhouse gas emissions when changing open dumps to landfills. Therefore, the aims of this study were as follows: (1) to evaluate the feasibility of restructuring the existing landfills; (2) reveal the influence of upgrading open dumps through restructuring based on leachate control; and (3) explore the effects of landfill restructuring on $\mathrm{CO}_{2}$ emissions reduction.

\section{Methods and Data}

\subsection{Study Area}

Nanjing is located at north latitude $31^{\circ} 14^{\prime \prime}$ to $32^{\circ} 37^{\prime \prime}$ and east longitude $118^{\circ} 22^{\prime \prime}$ to $119^{\circ} 14^{\prime \prime}$ [25]. Over the past 30 years, the amount of MSW has increased from 0.884 million tons to 3.139 million tons, and it will reach 3.6 and 4.9 million tons in the years 2020 and 2030, respectively [26] (Figure 1a). Meanwhile, the urban population has increased from 2.644 million to 6.704 million, and the urban gross domestic product (GDP) in Nanjing has also increased from 65.82 billion CNY to 10,503.02 billion CNY. The continued growth of the city population and GDP presents a positive relationship with the amount of MSW (Figure 1b,c).

In Nanjing, low hill areas account for $60.8 \%$ of the territory, which provides excellent location conditions for landfill site selection. The construction process of Nanjing's landfills is tortuous. Nanjing ended the long-term historical policy of municipal garbage piled up randomly in 1993 due to the creation of the national "health and civilization city". Three landfill sites including Shuige, Jiaozishan, and Tianjingwa were constructed successively to dispose of MSW centrally based on better city zoning sites. In 2003, according to the relevant requirements issued by the Chinese government, the second stage of expansion projects was carried out on the Jiaozishan and Tianjingwa landfills using anti-seepage measures and the corresponding sewage treatment process. After 2004, the Tongiing and Ma'anshan landfills were built. Currently, there are five regular landfills and four open dumps in Nanjing (Figure 2). 


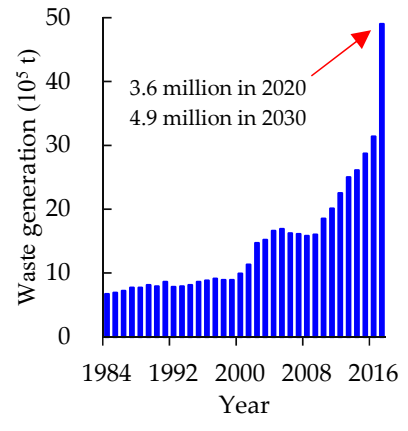

(a)

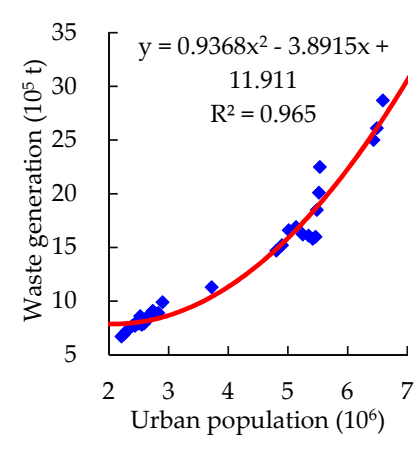

(b)

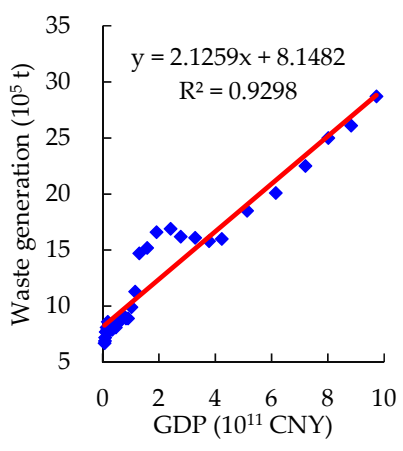

(c)

Figure 1. The growth of municipal solid waste (MSW) generation (a) and its correlation with population (b) and gross domestic product (GDP) (c) in Nanjing.

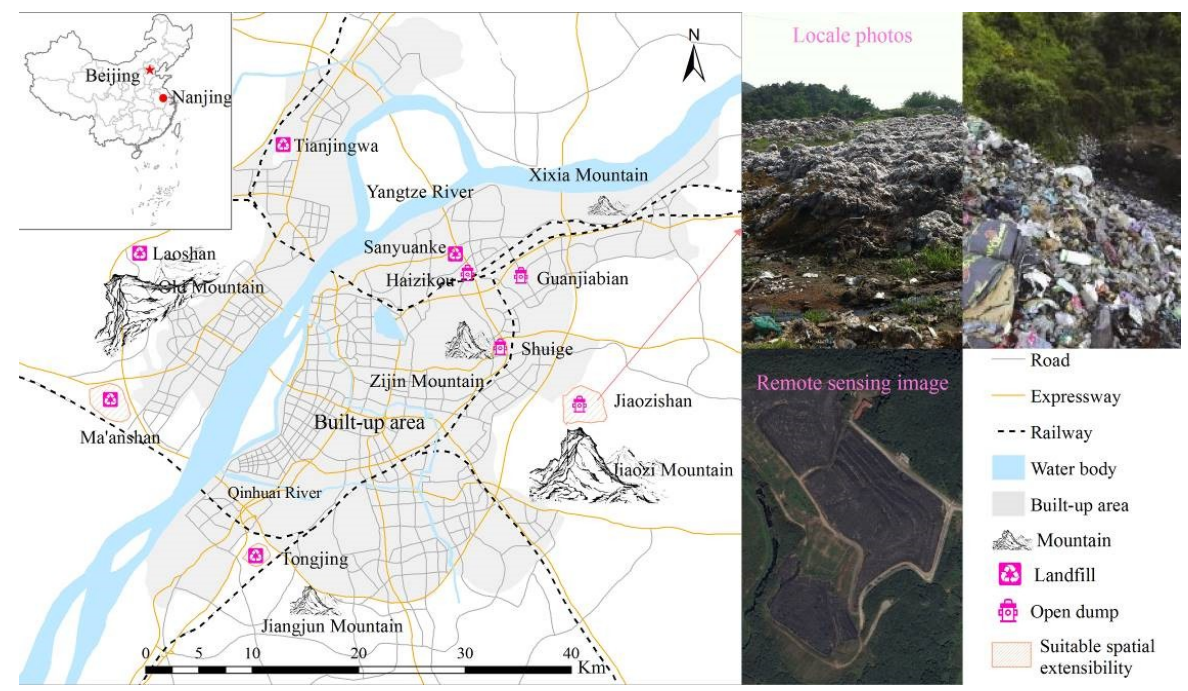

Figure 2. Location and landscape characteristics of five regular landfills and four open dumps in Nanjing.

The characteristics of five regular landfills and four open dumps in Nanjing are shown in Table 1. The four historical open dumps are typical decay landfills, which seriously threaten the ecological environment of the surrounding areas. The daily treatment capacity of these landfills is only 5600 tons, which is far below the $8600 \mathrm{t} \cdot \mathrm{d}^{-1}$ required by MSW management. Landfills and open dumps are overloaded to cope with the rapid growth of urban MSW output, even if they do not comply with current environmental standards. Therefore, it is imperative to restructure and upgrade the existing landfills and open dumps.

Table 1. Characteristics of five regular landfills and four open dumps in Nanjing.

\begin{tabular}{ccccc}
\hline Site & Type & $\begin{array}{c}\text { Area } \\
\mathbf{( h m}^{\mathbf{2}} \mathbf{)}\end{array}$ & Treatment Capacity $\mathbf{( \mathbf { t } \cdot \mathbf { d } ^ { \mathbf { - 1 } } \text { ) }}$ & Remaining Service Life (Years) \\
\hline Jiaozishan (JZS) & Open dump to landfill & 45.0 & 2600.0 & 13 \\
Tongjing (TJ) & Sanitary landfill & 34.4 & 2400.0 & 15 \\
Tianjingwa (TJW) & Sanitary landfill & 2.2 & 800.0 & 2 \\
Shuige (SG) & Open dump & 0.4 & 0 & Prohibited use \\
Maanshan (MAS) & Sanitary landfill & 17.2 & 1200.0 & 9 \\
Lanshan (LS) & Controlled & 7.8 & 800.0 & 11 \\
Haizikou (HZK) & Open dump & 0.3 & 100.0 & Limited use \\
Guanjiabian (GJB) & Open dump & 0.5 & 100.0 & Limited use \\
Sanyuanke (SYK) & Controlled & 4.1 & 400.0 & Over service life \\
\hline
\end{tabular}




\subsection{Research Methods}

\subsubsection{Research Framework}

A framework for landfill restructuring was formulated to effectively control the output of leachate and outflow pollution, meet the national environmental protection requirements, reduce leachate treatment costs, and achieve energy-saving emissions reduction targets (Figure 3). This framework consists of four steps.

Step I: Assessment of the feasibility of landfill site upgrade by combining analytic hierarchy process (AHP) with GIS [27]. If the locations of existing landfills were suitable, they were considered for the possibility of an upgrade. However, if they were not, they would be abandoned and a new suitable site selected.

Step II: A public perception survey was used to evaluate the total value loss that may result from upgrading the landfills as well as to determine the feasibility of the spatial extension of upgrading existing landfills [28,29].

Step III: A reasonable zoning plan was conducted for landfill upgrading. The pre-landfill sites were closed, while the arranged rain drainage system with the "separation of rainwater and sewage" method was used in long-term landfill sites, which could reduce the leachate output and slow down the effect of landfill leachate on the surrounding soil and groundwater environment [30].

Step IV: To achieve low-carbon landfill operations in the future, it is important to make full use of biogas power generation in the landfill and use the vacant land to build photovoltaic power plants.

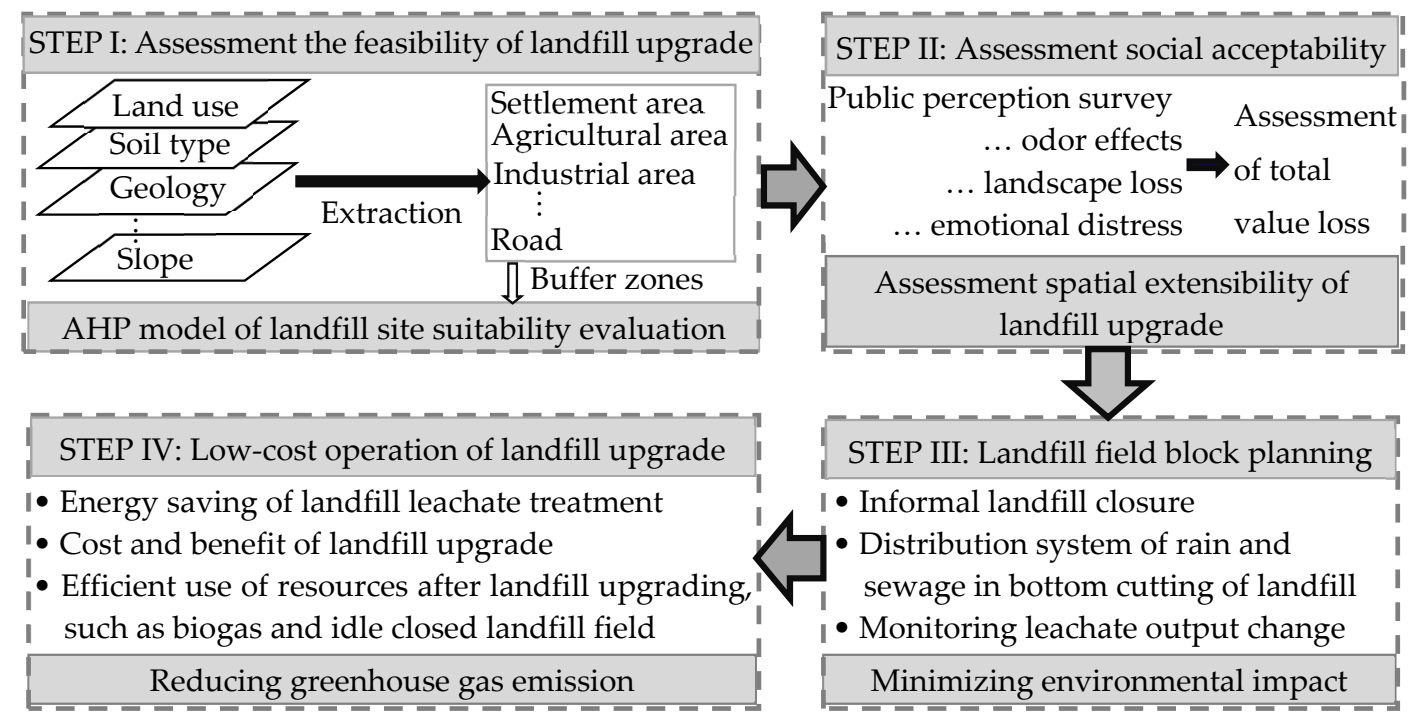

Figure 3. A framework for reducing greenhouse gas emissions from open dumps through infrastructure restructuring in this study.

\subsubsection{Review of Landfill Upgrading Plan and Leachate Estimation}

The landfill upgrading zoning plan has been implemented since 1 July 2011 [31]. In the early dump stage, the government improved the incomplete planted final cover-defective to the planted final cover-intact of $84,000 \mathrm{~m}^{2}$. Second, the plan was to accelerate the landfill work of the remaining area of the early dump stage and to implement the closure of all early-stage dumps in 2014. Third, it was to complete the $68,000 \mathrm{~m}^{2}$ of the covered landfill area of the first expansion stage and carry out no planting coverage. Next, to divide the remaining $92,000 \mathrm{~m}^{2}$ of the first expansion stage into two blocks, $44,000 \mathrm{~m}^{2}$ was to be constructed as untreated landfill area, and the remaining $48,000 \mathrm{~m}^{2}$ used for the implementation of separation of rainwater and sewage. Finally, the plan divided the $170,000 \mathrm{~m}^{2}$ of the second expansion stage into four blocks. No treatment was created from the $45,000 \mathrm{~m}^{2}$ start area, while the remaining $125,000 \mathrm{~m}^{2}$ was divided into three pieces to carry out the separation of rainwater and sewage plan. 
Previous studies have reported that the method of separation of rainwater and sewage would not only alleviate the environmental risk of large amounts of leachate infiltration but will also realize the reduction of $\mathrm{CO}_{2}$ emissions from the landfill operation process [32]. The following empirical formula can be used to calculate the output of landfill leachate [30,33,34].

$$
Q=I \sum_{i=1}^{n} C_{i} A_{i}
$$

where $Q$ represents the leachate output; I represents the average annual rainfall; $n$ represents the blocks number of landfill partition; $C_{i}$ represents the permeability coefficient of $i$ block, and $A_{i}$ indicates the catchment area of $i$ block. $C_{i}$ ranges from 0.1 to 0.8 , which is affected by many factors, such as precipitation, evaporation, and the upper cover. According to the similar parameters of Yang et al. [35] in Shanghai and CNS [36], the $C_{i}$ values in Nanjing are 0.7, 0.5, 0.2, 0.1, and 0.4, which correspond to landfill without cover, intermediate cover, unplanted final cover, planted final cover-intact, and planted final cover-defective, respectively. $I$ is a constant, and $C_{i}$ is the limited constant. Therefore, if $Q$ is proportional to $A_{i}$, then the leachate output can be effectively reduced by using zoning planning and separation of rainwater and sewage method to decrease $A_{i}$.

\subsubsection{Accounting Methods of $\mathrm{CO}_{2}$ Emissions Reduction}

Greenhouse gas (GHG) emission categories of the landfill can be divided into seven parts including $\mathrm{CO}_{2}$ emissions from waste collection and transportation, $\mathrm{CO}_{2}$ emissions from landfill management, $\mathrm{CO}_{2}$ emissions from leachate treatment, $\mathrm{GHG}$ emissions due to fugitive $\mathrm{CH}_{4}$, saved $\mathrm{CO}_{2}$ emissions as a substitute for electricity production, saved $\mathrm{CO}_{2}$ emissions as carbon sequestered in the landfill body, and other GHG emissions such as $\mathrm{NO}_{2}$ and $\mathrm{CO}$ emissions [35]. The effects of landfill restructuring on $\mathrm{CO}_{2}$ emissions have focused on $\mathrm{CO}_{2}$ emissions from the leachate treatment and saved $\mathrm{CO}_{2}$ emissions as a substitute for electricity production. Either the restructuring had a minimal effect on the $\mathrm{CO}_{2}$ emissions of the other parts, or the effect could not be accurately estimated.

In the first part, the $\mathrm{CO}_{2}$ emission reduction effect was caused by the reduced leachate after closing open dumps and the transformation of regular landfill using the separation of rainwater and sewage method, resulting in a decrease in energy consumption by the pollution treatment. First, the reduced leachate output was calculated according to Equation (1). Then, the Yang et al. [35] method was used to go through the variable transformation and combine the previous empirical parameters, and the $\mathrm{CO}_{2}$ emissions reductions were finally calculated [31,37]. The specific formula is as follows:

$$
C_{L T}=Q_{r} \times \sum_{i=1}^{n}\left(A_{i} \times E F_{i}\right) / 1000
$$

where $C_{L T}$ represents the annual $\mathrm{CO}_{2}$ emissions reduction from the leachate treatment $(t) ; Q_{r}$ represents the volume of leachate generated from the annual landfill reduction $\left(\mathrm{m}^{3}\right) ; A_{i}$ represents the amount of the $i$ th auxiliary material or energy used in the leachate treatment process (Table 2), and $E F_{i}$ represents the $\mathrm{CO}_{2}$ emissions factor for the provision of the $i$ th auxiliary material or energy $\left(\mathrm{kg} \mathrm{kg}^{-1} \mathrm{or} \mathrm{kg} \cdot \mathrm{kWh}^{-1}\right)$.

Table 2. Parameters used in the greenhouse gas (GHG) accounting formula for landfill restructuring.

\begin{tabular}{ccccc}
\hline Parameters & Definition & Values & Units & References \\
\hline $\mathrm{A}_{\text {Gravel }}$ & Amount of gravel used for leachate collection & $80-120$ & $\mathrm{~kg} \cdot \mathrm{t}^{-1} \mathrm{waste}$ & {$[38]$} \\
$\mathrm{A}_{\text {Electricity }}$ & $\begin{array}{c}\text { Amount of electricity used for official landfill systems, } \\
\text { operation of leachate, and landfill gas collection system }\end{array}$ & $22-26$ & $\mathrm{kWh} \cdot \mathrm{m}^{-3}$ & {$[37,38]$} \\
$\mathrm{A}_{\text {Water }}$ & Amount of water used for the leachate treatment & 83 & $\mathrm{~kg} \cdot \mathrm{m}^{-3}$ & {$[37]$} \\
$\mathrm{A}_{\mathrm{HCl}}$ & Amount of $\mathrm{HCl}$ used for the leachate treatment & 3 & $\mathrm{~kg} \cdot \mathrm{m}^{-3}$ & {$[37]$} \\
$\mathrm{A}_{\mathrm{NaOH}}$ & Amount of $\mathrm{NaOH}$ used for the leachate treatment & 5 & $\mathrm{~kg} \cdot \mathrm{m}^{-3}$ & {$[37]$} \\
\hline
\end{tabular}


Second, the biogas produced by the reformed landfill was utilized comprehensively, then, the amount of $\mathrm{CH}_{4}$ that escaped was reduced, which led to greenhouse gas effects. The available quantity of $\mathrm{CH}_{4}$ converted into the equivalent $\mathrm{CO}_{2}$ value could be calculated according to the formula listed by the IPCC (Intergovernmental Panel on Climate Change) Guidelines [39], and the specific formula is as follows:

$$
C_{S E}=P_{C_{4}} \times M C F \times \frac{24.5 \mathrm{~L} \cdot \mathrm{mol}^{-1}}{16 \mathrm{~g} \cdot \mathrm{mol}^{-1}} \times \beta \times \varepsilon \times L H W_{C H_{4}} \times \gamma \times \frac{1}{3.6 \mathrm{MJ} \cdot \mathrm{kWh}^{-1}} \times E F_{e} / 1000
$$

where $C_{S E}$ represents the saved $\mathrm{CH}_{4}$ emissions as substituted $\mathrm{CO}_{2}$ emissions from electricity production (t); $P_{\mathrm{CH} 4}$ represents the $\mathrm{CH}_{4}$ potential of waste under anaerobic conditions, which was $36.3 \pm 8.5 \mathrm{~kg} \cdot \mathrm{t}^{-1}$ in this study [40]; MCF is the $\mathrm{CH}_{4}$ conversion factor, which was 0.8 before 2016 and 1.0 after 2020 in this study [41]; $\beta$ represents the LFG (Landfill Gas) collection efficiency, which was $50 \%$ in this study [42]; $\varepsilon$ represents the $\mathrm{CH}_{4}$ burnout rate, which was $95-99 \%$ in this study [38]; $L H V_{C H 4}$ represents the lower heating value of $\mathrm{CH}_{4}$ under normal conditions (i.e., $101 \mathrm{kPa}, 25{ }^{\circ} \mathrm{C}$, $\mathrm{MJ} \cdot \mathrm{m}^{-3}$ ), which was $37 \mathrm{MJ} \cdot \mathrm{m}^{-3}$ in this study [38]; $\gamma$ represents the energy recovery efficiency for the electricity generation from $\mathrm{CH}_{4}$ combustion, which was $30 \%$ in this study; and $E F_{e}$ represents the $\mathrm{CO}_{2}$ emissions factor for the national power grid in China, which was $0.7035 \mathrm{~kg} \cdot \mathrm{kWh}^{-1}$ in this study [35].

In addition, photovoltaic power plants will be built on the vacant land after the closure of some landfills, which can replace the fossil fuel energy and realize low-carbon operations. According to the construction standard of China's thin-film solar power stations and the annual average sunshine time in Nanjing, the annual power generation capacity of the solar power station was calculated by the substitution method and then converted to the $\mathrm{CO}_{2}$ equivalent value. The calculation formula is as follows:

$$
C_{\text {solar }}=A \times e \times h \times r \times E F_{e}
$$

In the formula, $C_{\text {solar }}$ indicates the converted electricity $\mathrm{CO}_{2}$ equivalent value, which is an alternative emission reduction potential; $A$ indicates the available area of covered vacant land of the landfill $\left(\mathrm{m}^{2}\right.$, approximately $60 \%$ of the overlying vacant land can be used for photovoltaic power generation); $e$ indicates the photovoltaic power in kilowatt hours per unit area $\left(1 \mathrm{ha} \cdot \mathrm{MW}^{-1}\right)$, according to the design specifications of the photovoltaic power station [43] and land control index of the photovoltaic power station project [43]); $h$ indicates the annual sunshine time; $r$ indicates the comprehensive utilization coefficient 0.80 [43], and $E F_{e}$, is the same as above.

\subsection{Data Collection and Processing}

In January 2015, we were commissioned by the Nanjing Environmental Protection Bureau to conduct this study. Detailed information was collected for each of the nine landfills, such as storage capacity, landfill, and leachate treatment. Additionally, the groundwater quality data of monitoring the wells in the Jiaozishan (JZS) landfill were collected. In February and August of 2015, the JZS landfill leachate collection tank, monitoring wells, surrounding agricultural wells, and drilling borehole water samples were also collected, processed, and analyzed according to Network Service Provider Reliability Council [44] and Du et al. [45]. The 1:10,000 land use map, 1:50,000 geological map, soil type chart, QuickBird remote sensing image of 29 July 2015 (resolution $0.61 \mathrm{~m}$ ), and other information were collected from the Land Resources Bureau. The AHP and perceived value loss calculation models were both constructed based on the results of related research. The SPSS19.0 software was used to analyze the data and correlate the analysis. ARCGIS 10.2 software was used to perform the overlay and buffer analysis of land use, soil type, geology, hydrology, and road distance. 


\section{Results}

\subsection{Feasibility Analysis of Landfill and Open Dump Upgrade}

The AHP model was used to evaluate the feasibility of upgrading five landfills and four open dumps in Nanjing. The results showed that only three of the five landfills could continue with upgrades, while Tianjingwa (TJW) and Sanyuanke (SYK) have been surrounded by urban built area. These were not suitable as the landfills and should be immediately closed. Only the JZS landfill was suitable for upgrading among the four open dumps, whereas the other three did not meet the basic upgrading conditions (Table 3).

Table 3. The results of the evaluation of the feasibility of upgrading five landfills and four open dumps in Nanjing.

\begin{tabular}{|c|c|c|c|c|c|c|c|c|c|c|}
\hline Limiting Factor & Limiting Sub-Factor & JZS & TJ & TJW & SG & MAS & LS & HZK & GJB & SYK \\
\hline \multirow{7}{*}{$\begin{array}{l}\text { Environmental } \\
\text { geological factor }\end{array}$} & Topography conditions & 5 & 3 & 5 & 3 & 5 & 5 & 3 & 5 & 5 \\
\hline & Site stability & 5 & 5 & & 5 & 5 & 5 & 5 & 5 & 5 \\
\hline & Distance from water source & 5 & 3 & 5 & 3 & 5 & 5 & 3 & 3 & 3 \\
\hline & Bottom cohesive soil thickness & 5 & 5 & 5 & 5 & 5 & 5 & 5 & 3 & 5 \\
\hline & Sidewall cohesive soil thickness & 3 & 5 & 3 & 5 & 5 & 3 & 5 & 3 & 5 \\
\hline & Permeability of cohesive soil & 3 & 5 & 3 & 3 & 5 & 5 & 5 & 5 & 5 \\
\hline & Groundwater depth & 5 & 3 & 3 & 3 & 3 & 5 & 3 & 3 & 3 \\
\hline \multirow{4}{*}{$\begin{array}{l}\text { Environmental } \\
\text { protection factor }\end{array}$} & Distance from surface water & 5 & 3 & 5 & 1 & 3 & 5 & 1 & 3 & 1 \\
\hline & Distance from settlements & 3 & 3 & $x$ & $x$ & 5 & 5 & $x$ & $x$ & $x$ \\
\hline & Distance from town & 5 & 5 & $x$ & $x$ & 5 & 5 & $x$ & $x$ & $x$ \\
\hline & Distance from industrial area & 3 & 3 & $x$ & 3 & 3 & 3 & $x$ & $x$ & $x$ \\
\hline \multirow{2}{*}{$\begin{array}{c}\text { Traffic and } \\
\text { transportation factor }\end{array}$} & Distance from existing highway & 5 & 5 & 5 & 5 & 5 & 5 & 5 & 5 & 5 \\
\hline & Garbage transport distance & 5 & 3 & 5 & 5 & 3 & 3 & 5 & 5 & 5 \\
\hline \multirow{6}{*}{$\begin{array}{l}\text { Social environmental } \\
\text { factor }\end{array}$} & Distance from scenic area & 5 & 5 & 5 & 3 & 5 & 1 & 3 & 3 & 3 \\
\hline & Distance from railway & 3 & 5 & 3 & 3 & 5 & 5 & 1 & $x$ & 3 \\
\hline & Distance from airport & 5 & 5 & 5 & 5 & 5 & 5 & 5 & 5 & 5 \\
\hline & Population number within $1000 \mathrm{~m}$ & 5 & 3 & $x$ & 1 & 5 & 5 & $x$ & $x$ & $x$ \\
\hline & Population number within $1500 \mathrm{~m}$ & 5 & 3 & $x$ & 1 & 3 & 5 & $x$ & $x$ & $x$ \\
\hline & Population number within $2000 \mathrm{~m}$ & 3 & 3 & $x$ & 3 & 3 & 5 & $x$ & $x$ & $x$ \\
\hline \multicolumn{2}{|c|}{ Anti-evaluation results } & $\checkmark$ & $\checkmark$ & $x$ & $x$ & $\checkmark$ & $\checkmark$ & $x$ & $x$ & $x$ \\
\hline
\end{tabular}

Notes: scoring criteria: completely suitable, 5 points; generally suitable, 3 points; limited suitability, 1 point; completely unsuitable, $\boldsymbol{X}$; once there is a completely unsuitable score, the comprehensive result is unfeasible. $\checkmark$ means suitable for upgrading.

\subsection{Influence of Upgrading Open Dumps through Restructuring on Leachate}

At the beginning, the JZS landfill was an open dump with a daily treatment capacity of only 600 tons since it was opened with an area of $120,000 \mathrm{~m}^{2}$ in 1991, and it accumulated a stack of 4.7 million $\mathrm{m}^{3}$ until 2011. To cope with the continuous growth of MSW in Nanjing, the area of the JZS landfill was expanded twice in 2003 and 2011 at 160,000 $\mathrm{m}^{2}$ and 170,000 $\mathrm{m}^{2}$, respectively. The service was extended to 2030. The JZS landfill was expected to have a daily treatment capacity of 2600 tons for growing MSW generation after the second expansion. In addition, approximately $120,000 \mathrm{~m}^{2}$ carried out the implementation of the anti-seepage transformation in the first expansion, and $84,000 \mathrm{~m}^{2}$ of the early dump stage implemented the planted final cover-defective in 2008. Now, it is the largest landfill in Nanjing and has the largest daily treatment capacity (Table 1).

\subsubsection{Effects of Upgrading on the Leachate Output}

Due to the huge area of the JZS landfill, the costs of the leachate treatment by itself would have been very large if the scientific division was not carried out since the implementation of the new "Standard for Pollution Control on the Landfill Site of Municipal Solid Waste". The results based on 
the upgrading plan of the separation of rainwater and sewage zoning and the empirical formula of leachate estimation (Equation (1)) are shown in Table 4. The zoning plan could effectively control the leachate output. Compared with the data from 2011, the landfill area in 2015 expanded by about $60.7 \%$, while the actual leachate output decreased by $30.8 \%$. If the zoning planning had not been implemented, the possible maximum leachate output would be $124.7 \%$ higher than the actual output. The actual leachate output correlated with the theoretical leachate output $(p=0.01)$, and the Pearson correlation coefficient was approximately 0.9745 .

Table 4. The variation and forecast of leachate output before and after the upgrades to the JZS open dump.

\begin{tabular}{|c|c|c|c|c|c|c|c|c|c|c|c|}
\hline \multirow[b]{2}{*}{ Year } & \multirow[b]{2}{*}{$\begin{array}{c}\text { Annual } \\
\text { Rainfall } \\
\text { (mm) }\end{array}$} & \multirow[b]{2}{*}{$\begin{array}{c}\text { Area } \\
\left(10^{4} \mathrm{~m}^{2}\right)\end{array}$} & \multicolumn{6}{|c|}{ Coverage Status of Landfill Site } & \multirow{2}{*}{$\begin{array}{l}\text { The Maximum } \\
\text { Possible Leachate } \\
\text { Output Without } \\
\text { The Zoning } \\
\text { Plan }\left(\mathrm{m}^{3}\right)\end{array}$} & \multicolumn{2}{|c|}{ With the Zoning Plan } \\
\hline & & & A & B & $\mathrm{C}$ & D & E & $\mathbf{F}$ & & $\begin{array}{c}\text { Theoretical Leachate } \\
\text { Output }\left(\mathrm{m}^{3}\right)\end{array}$ & $\begin{array}{c}\text { Actual } \\
\text { Leachate } \\
\text { Output }\left(\mathrm{m}^{3}\right)\end{array}$ \\
\hline 2011 & 1077.0 & 28.0 & & 19.6 & & & & 8.4 & $183,951.6$ & $183,951.6$ & $174,436.2$ \\
\hline 2012 & 917.2 & 28.0 & & 16.0 & 3.6 & & & 8.4 & $150,053.9$ & $150,053.9$ & $161,245.4$ \\
\hline 2013 & 898.4 & 45.0 & & 33.0 & 3.6 & & 8.4 & & $231,248.2$ & $231,248.2$ & $237,389.5$ \\
\hline 2020 & 1106.5 & 45.0 & 12.5 & 8.5 & & 5.2 & 18.8 & & $194,965.3$ & $98,146.6$ & \\
\hline 2030 & 1106.5 & 45.0 & & & & & 45.0 & & $49,792.5$ & $49,792.5$ & \\
\hline
\end{tabular}

Note: A separation of rainwater and sewage area; B uncovered area; C intermediate cover; D unplanted final cover; E planted final cover-intact; and F planted final cover-defective.

\subsubsection{Mitigation of Leachate Concentration by Restructuring}

There are various physicochemical indices for leachates. For a concise comparison analysis, we only selected the $\mathrm{COD}, \mathrm{TN}, \mathrm{Cl}^{-}$, and $\mathrm{Cr}$, which represented the inherent stability of organic and inorganic compounds and heavy metals [46]. The JZS landfill daily water quality monitoring data and borehole sampling analysis results in February and August of 2011 and 2016 are shown as follows (Figure 4). The COD, TN, Cl, and $\mathrm{Cr}$ contents were highest in the leachate collection pond, and the concentrations in the landfill surrounding the monitoring well were slightly lower, while the concentrations in the surrounding agricultural well water and borehole water sampling were the lowest. Compared with 2011, the COD content changed the most in 2016, and the decline rate was up to $17.6 \%$. The changes of other indicators were relatively small, but the overall index in 2016 was better than that in 2011. These results imply that the JZS landfill has effectively mitigated the pollution of leachates to the surrounding groundwater.

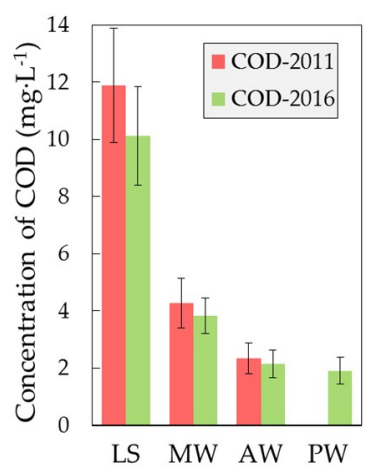

(a)

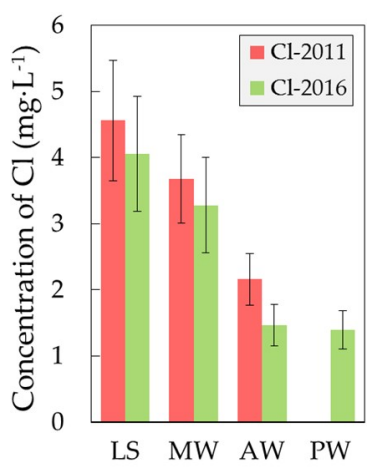

(b)

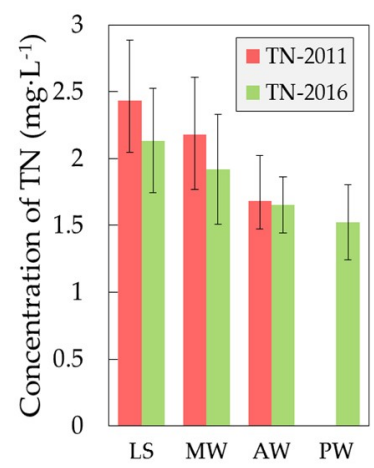

(c)

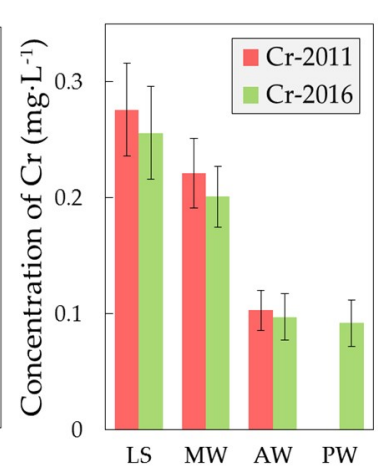

(d)

Figure 4. Changes in physicochemical characteristics besides $\mathrm{COD}(\mathbf{a}), \mathrm{Cl}(\mathbf{b}), \mathrm{TN}(\mathbf{c})$, and $\mathrm{Cr}(\mathbf{d})$ of leachate before (2011) and after (2016) restructuring. LS stands for leachate sumps, $n=4$ samples $\times 2$ periods; MW stands for monitoring well, $n=8$ samples $\times 2$ periods; AW represents agricultural well, $n=5$ samples $\times 2$ periods; PW represents pore water, $n=11$ samples $\times 2$ periods. 


\subsection{Effect of Landfill Restructuring on $\mathrm{CO}_{2}$ Emission Reduction}

According to Equations (2)-(4) and Table 4, the contributions of leachate output reductions caused by landfill restructuring, biogas power generation replacing fossil energy, and photovoltaic power generation to $\mathrm{CO}_{2}$ emission reductions were each calculated separately. After landfill restructuring, the actual leachate output decreased by approximately $10,188.9 \mathrm{~m}^{3}$. At the same time, biogas could be collected by sealing the areas of the open dump stage and the first upgrading stage, and a solar power station built on the vacant upper covering land (Table 4). The annual $\mathrm{CO}_{2}$ emissions were approximately $48,000-55,000$ tons in 2015 , and the $\mathrm{CO}_{2}$ emissions reductions each year after 2030 may reach approximately $80,400-86,000$ tons (Figure 5). The benefits of $\mathrm{CO}_{2}$ emissions reductions brought by the leachate treatment were significant in the initial stage. With the gradual closure of the landfill site, the area of rainwater diversion at the bottom of the field was reduced, and there was no obvious role of leachate output reduction.

Meanwhile, the JZS landfill was very large with many closed staging blocks, which is important for biogas power with a stable source of biogenic gas. After the closure of the landfill, a solar power plant will be built on the vacant upper covering land of the landfill. Other benefits in addition to $\mathrm{CO}_{2}$ emissions reductions of the solar power plant are shown as follows:

(1) Upper covering vacant land resources are effectively used.

(2) It helps to alleviate the lack of space for construction land available in major cities in China.

(3) A practical approach of low-carbon and sustainable management for post-landfilling operations is provided to achieve $\mathrm{CO}_{2}$ emissions reductions and alleviate financial pressure on the government. Regardless of carbon rights trading, the photovoltaic electric tariff charged up to 20-40 million CNY, which can fully meet the funding requirements of the daily landfill operation and management after landfill closure.

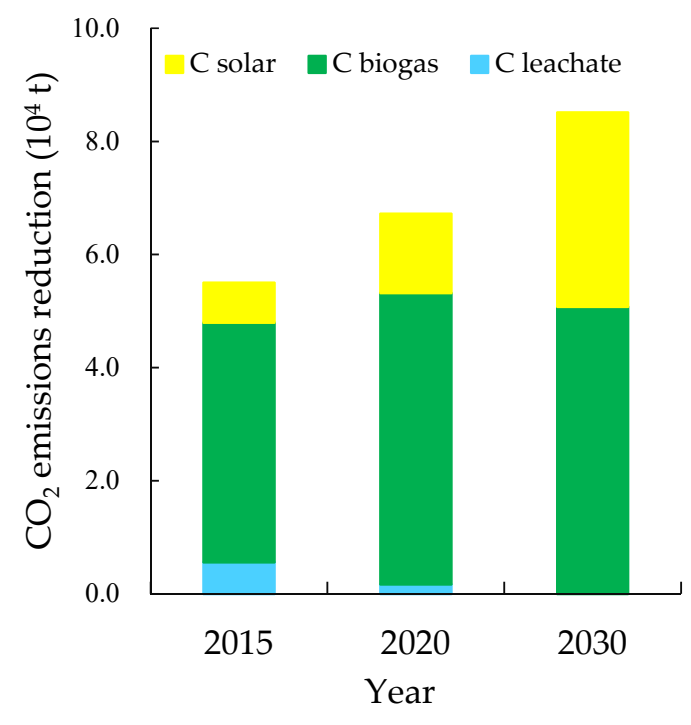

Figure 5. The contribution of $\mathrm{CO}_{2}$ emissions reductions through landfill restructuring.

\section{Discussion}

MSW is an important carbon source; its recycling and $\mathrm{CO}_{2}$ emissions reduction potential have always been a research hotspot [47-50]. From the estimated results, the benefits of landfill restructuring are obvious. The results showed that biogas power generation replacing fossil energy could save $45,000-60,000$ tons of $\mathrm{CO}_{2}$ emissions per year. Considering the life cycle of the landfill, the saved $\mathrm{CO}_{2}$ emissions of the biogas power generation from the JZS landfill accounted for $33.2-44.3 \%$ of the total $\mathrm{CO}_{2}$ emissions of the entire MSW disposal. This ratio was slightly lower than the proportion 
of 40.0-60.0\% $\mathrm{CO}_{2}$ emissions reduction in China's landfill gas generation alternative to fossil fuels that was estimated by Yang et al. [35], while it was higher than that in some developing countries [41]. In fact, the proportion of saved $\mathrm{CO}_{2}$ emissions from the incineration of MSW was higher and reached up to $80 \%$ or higher in some countries [51]. Incineration treatment in landfills should be vigorously promoted from the perspective of $\mathrm{CO}_{2}$ emissions reduction.

Furthermore, local governments should focus on environmental protection measures of landfill restructuring and convince the public of its benefits [4,19]. Previous studies have focused on the risk of landfills from natural risks, social risks, and financial risks. The natural risks of landfills were comprehensively assessed regarding topographic, geological, hydrological, soil, and land use factors [52-54]. The social risks of the landfills were entirely determined regarding agricultural land, residential areas, industrial zones, and scenic spots $[28,55,56]$. The financial risks of landfills were adequately estimated according to the distance from the landfill to highways and railways $[57,58]$. In this study, all of the environmental, hydrological, and geological factors were considered when restructuring the open dumps. Furthermore, these risks were significantly reduced after the implication of separation of rainwater and sewage zoning planning.

The operation and management of closed landfills is another important problem [13]. Most countries have primarily used general upper covering vacant land of closed landfills as country parks [59]. However, these parks have been much criticized by the public due to their poor location, poor security, low utilization rate, and high operating costs [60]. The planning of landfill for parks has made operating costs a long-term burden for local governments in major cities in China. Therefore, long-term and stable income is especially important for post-landfill operation and management [16]. We suggest here that a solar power station would be a priority for the upper covering vacant land. After being fully closed in 2030, the vacant land is conservatively estimated to be enough to build $30 \mathrm{MW}$ photovoltaic power stations, which is equivalent to an annual saving of $26,000-30,000$ tons of $\mathrm{CO}_{2}$. At the same time, the photovoltaic power station could generate 20-40 million CNY from the annual electricity sales, which could fund approximately 20 years of continuous operation and management of the landfill after closure, which is also very attractive to government policy-makers.

In this study, the upgraded landfill site could effectively reduce greenhouse gas emissions, which has enhanced confidence and provided technical references for the large number of open dumps in developing countries. However, unlike transportation, electricity, and the water supply, landfill development planning has not yet received government attention $[16,61,62]$. Landfills and open dumps are overloaded to cope with the rapid growth of urban MSW output, even if they do not comply with current environmental standards. Therefore, it is imperative to restructure and upgrade the existing landfills and open dumps in developing countries in the future.

\section{Conclusions}

As China's environmental standards for MSW disposal have become increasingly stricter, many informal landfills cannot meet the requirements of environmental protection and must upgrade through restructuring. We established a technical process in this study that is applicable for upgrading open dumps in China. An analytic hierarchy process model was used to evaluate five landfills and four dumps based on field investigations in Nanjing. The results showed that only four sites were suitable for upgrading and restructuring. After the upgrading and restructuring of the JZS landfill using the bottom separation of rainwater and sewage zoning planning, the actual leachate output was reduced by $5.84 \%$, far less than $120 \%$ of the maximum possible leachate output without zoning planning. Biogas power generation replacing fossil energy could save 45,000-60,000 t. year ${ }^{-1}$ of $\mathrm{CO}_{2}$ emissions, which account for $33.2-44.3 \%$ of $\mathrm{CO}_{2}$ emissions from the total MSW disposal. The upper covering vacant land of the post-landfill can be used to build a photovoltaic power station, which could not only reduce $26,000-30,000 \mathrm{t} \cdot \mathrm{year}^{-1}$ of $\mathrm{CO}_{2}$ emissions but will also generate $20-40$ million $\mathrm{CNY}$ annually from the sale of electricity. These funds would be beneficial in alleviating the continuous financial pressure of post-landfill operation and management in the future. 
Author Contributions: J.M., Z.L., Q.Z. and S.Z. performed all the experiments and drafted the manuscript. All authors participated in the design of this study and analysis of results. F.C. and G.L. conceived and coordinated this study.

Funding: This research was funded by the Major Project in the Fundamental Research Funds for the Central Universities grant number No.2017XKZD14.

Acknowledgments: The authors would like to thank the Environment Protection Agency of Nanjing City for its support during the research. The authors would like to thank MDPI English Service for providing linguistic assistance during the preparation of this manuscript.

Conflicts of Interest: The authors declare no conflict of interest. The funders had no role in the design of the study; in the collection, analyses, or interpretation of data; in the writing of the manuscript, and in the decision to publish the results.

\section{References}

1. Ali, M. Urban waste management as if people matter. Habitat Int. 2006, 4, 729-730. [CrossRef]

2. Hoornweg, D.; Bhada-Tata, P.; Kennedy, C. Environment: Waste production must peak this century. Nature 2013, 502, 615-617. [CrossRef] [PubMed]

3. National Bureau of Statistics of China (NSBC). China Urban Statistical Yearbook. Available online: http:/ / www.stats.gov.cn/tjsj/ndsj/2016/indexch.htm (accessed on 6 June 2017).

4. Chen, F.; Luo, Z.; Yang, Y.; Liu, G.-J.; Ma, J. Enhancing municipal solid waste recycling through reorganizing waste pickers: A case study in Nanjing, China. Waste Manag. Res. 2018. [CrossRef] [PubMed]

5. Zaman, A.U.; Lehmann, S. Urban growth and waste management optimization towards 'zero waste city'. City Cult. Soc. 2011, 2, 177-187. [CrossRef]

6. Hird, M.J. Waste, landfills, and an environmental ethic of vulnerability. Ethics Environ. 2013, 18, 105-124. [CrossRef]

7. Han, H.; Zhang, Z.; Xia, S. The crowding-out effects of garbage fees and voluntary source separation programs on waste reduction: Evidence from China. Sustainability 2016, 8, 678. [CrossRef]

8. Han, H.; Zhang, Z. The impact of the policy of municipal solid waste source-separated collection on waste reduction: A case study of China. J. Mater. Cycles Waste Manag. 2017, 19, 382-393. [CrossRef]

9. Wang, Y.; Cheng, K.; Wu, W.; Tian, H.; Yi, P.; Zhi, G.; Fan, J.; Liu, S. Atmospheric emissions of typical toxic heavy metals from open burning of municipal solid waste in China. Atmos. Environ. 2017, 152, 6-15. [CrossRef]

10. Chan, J.K.H. The ethics of working with wicked urban waste problems: The case of Singapore's Semakau Landfill. Landsc. Urban Plan. 2016, 154, 123-131. [CrossRef]

11. Zaman, A.U. Comparative study of municipal solid waste treatment technologies using life cycle assessment method. Int. J. Environ. Sci. Technol. 2010, 7, 225-234. [CrossRef]

12. Adamcová, D.; Vaverková, M.D.; Bartoň, S.; Havlíček, Z.; Břoušková, E. Soil contamination in landfills: A case study of a landfill in Czech Republic. Solid Earth 2016, 7, 239-247. [CrossRef]

13. Panepinto, D.; Senor, A.; Genon, G. Energy recovery from waste incineration: Economic aspects. Clean Technol. Environ. Policy 2016, 18, 517-527. [CrossRef]

14. Idris, A.; Inanc, B.; Hassan, M.N. Overview of waste disposal and landfills/dumps in Asian countries. J. Mater. Cycles Waste Manag. 2004, 6, 104-110. [CrossRef]

15. Xevgenos, D.; Papadaskalopoulou, C.; Panaretou, V.; Moustakas, K.; Malamis, D. Success stories for recycling of MSW at municipal level: A review. Waste Biomass Valoriz. 2015, 6, 657-684. [CrossRef]

16. Zhang, D.Q.; Tan, S.K.; Gersberg, R.M. Municipal solid waste management in China: Status, problems and challenges. J. Environ. Manag. 2010, 91, 1623-1633. [CrossRef] [PubMed]

17. Reichert, A.; Small, M.; Mohanty, S. The impact of landfills on residential property values. J. Real Estate Res. 1992, 7, 297-314.

18. Reyes-López, J.A.; Ramírez-Hernández, J.; Lázaro-Mancilla, O.; Carreón-Diazconti, C.; Garrido, M.M.-L. Assessment of groundwater contamination by landfill leachate: A case in México. Waste Manag. 2008, 28, S33-S39. [CrossRef] [PubMed]

19. Bortone, I.; Chianese, S.; Erto, A.; Di Nardo, A.; Di Natale, M.; Santonastaso, G.F.; Musmarra, D. Risk Analysis for a Contaminated Site in North of Naples (Italy). Chem. Eng. Trans. 2015, 43, 1927-1932. 
20. Inglezakis, V.J.; Moustakas, K. Household hazardous waste management: A review. J. Environ. Manag. 2015, 150, 310-321. [CrossRef] [PubMed]

21. Di Nardo, A.; Bortone, I.; Chianese, S.; Di Natale, M.; Erto, A.; Santonastaso, G.F.; Musmarra, D. Odorous emission reduction from a waste landfill with an optimal protection system based on fuzzy logic. Environ. Sci. Pollut. Res. 2018. [CrossRef] [PubMed]

22. Danthurebandara, M.; Van Passel, S.; Vanderreydt, I.; Van Acker, K. Assessment of environmental and economic feasibility of Enhanced Landfill Mining. Waste Manag. 2015, 45, 434-447. [CrossRef] [PubMed]

23. Tintner, J.; Smidt, E.; Boehm, K.; Matiasch, L. Risk assessment of an old landfill regarding the potential of gaseous emissions-A case study based on bioindication, FT-IR spectroscopy and thermal analysis. Waste Manag. 2012, 32, 2418-2425. [CrossRef] [PubMed]

24. Swati; Ghosh, P.; Thakur, I.S. An integrated approach to study the risk from landfill soil of Delhi: Chemical analyses, in vitro assays and human risk assessment. Ecotoxicol. Environ. Saf. 2017, 143, 120-128. [CrossRef] [PubMed]

25. Chen, F.; Li, X.; Ma, J.; Yang, Y.; Liu, G.-J. An Exploration of the Impacts of Compulsory Source-Separated Policy in Improving Household Solid Waste-Sorting in Pilot Megacities, China: A Case Study of Nanjing. Sustainability 2018, 10, 1327. [CrossRef]

26. EPA Outline of the Overall Environmental Planning of Nanjing (2016-2030). Available online: http:/ / www. nj.gov.cn/xxgk/szf/201703/t20170331_4421292.html (accessed on 6 June 2017).

27. Sener, S.; Sener, E.; Nas, B.; Karaguzel, R. Combining AHP with GIS for landfill site selection: A case study in the Lake Beysehir catchment area (Konya, Turkey). Waste Manag. 2010, 30, 2037-2046. [CrossRef] [PubMed]

28. Simsek, C.; Elci, A.; Gunduz, O.; Taskin, N. An improved landfill site screening procedure under NIMBY syndrome constraints. Landsc. Urban Plan. 2014, 132, 1-15. [CrossRef]

29. Vrijheid, M. Health effects of residence near hazardous waste landfill sites: A review of epidemiologic literature. Environ. Health Perspect. 2000, 108, 101-112. [CrossRef] [PubMed]

30. Zhang, C.; Zhu, X.-J.; Wang, Z.-Z. Separate System of Rainwater and Sewage in Sanitary Landfill. Environ. Sci. Technol. 2009, 32, 203-205.

31. Ministry of Housing and Urban-Rural Development. Technical Code for Leachate Treatment of Municipal Solid Waste (CJJ150-2010); Chinese Industrial Standard; China Architecture and Building Press: Beijing, China, 2010.

32. Albright, W.H.; Benson, C.H.; Gee, G.W.; Roesler, A.C.; Abichou, T.; Apiwantragoon, P.; Lyles, B.F.; Rock, S.A. Field water balance of landfill final covers. J. Environ. Qual. 2004, 33, 2317-2332. [CrossRef] [PubMed]

33. $\mathrm{Xu}, \mathrm{D}$. Energy-saving application of ground-floor rain-sewage diversion method in landfill site. Technol. Enterp. 2013, 185. [CrossRef]

34. El-Fadel, M.; Findikakis, A.N.; Leckie, J.O. Modeling Leachate Generation and Transport in Solid Waste Landfills. Environ. Technol. 1997, 18, 669-686. [CrossRef]

35. Yang, N.; Zhang, H.; Shao, L.M.; Lu, F.; He, P.J. Greenhouse gas emissions during MSW landfilling in China: Influence of waste characteristics and LFG treatment measures. J. Environ. Manag. 2013, 129, 510-521. [CrossRef] [PubMed]

36. Ministry of Housing and Urban-Rural Development. Technical Code for Domestic Waste Sanitary Landfill Pollution Control (GB16889-2008); Chinese National Standard; China Planning Press: Beijing, China, 2008.

37. Hehai Water Environmental Company (HWEC). Technology Design of Leachate Treatment Plant in Wanshan Landfill Site; Hehai Water Environmental Company: Nanjing, China, 2005.

38. Manfredi, S.; Tonini, D.; Christensen, T.H.; Scharff, H. Landfilling of waste: Accounting of greenhouse gases and global warming contributions. Waste Manag. Res. 2009, 27, 825-836. [CrossRef] [PubMed]

39. IPCC. 2006 IPCC Guidelines for National Greenhouse Gas Inventories. Intergovernmental Panel on Climate Change. Available online: https:/ / www.ipcc-nggip.iges.or.jp/meeting/pdfiles/Washington_Report.pdf (accessed on 6 June 2017).

40. Yang, N.; Zhang, H.; Chen, M.; Shao, L.-M.; He, P.-J. Greenhouse gas emissions from MSW incineration in China: Impacts of waste characteristics and energy recovery. Waste Manag. 2012, 32, 2552-2560. [CrossRef] [PubMed]

41. Tan, S.T.; Hashim, H.; Lim, J.S.; Ho, W.S.; Lee, C.T.; Yan, J. Energy and emissions benefits of renewable energy derived from municipal solid waste: Analysis of a low carbon scenario in Malaysia. Appl. Energy 2014, 136, 797-804. [CrossRef] 
42. Wanichpongpan, W.; Gheewala, S.H. Life cycle assessment as a decision support tool for landfill gas-to energy projects. J. Clean Prod. 2007, 15, 1819-1826. [CrossRef]

43. Ministry of Housing and Urban-Rural Development. Technical Code for Photovoltaic Power Station Design (GB50797-2012); Chinese Industrial Standard; China Architecture and Building Press: Beijing, China, 2012.

44. Network Service Provider Reliability Council. Water Quality Determination of the Chemical Oxygen Demand-Dichromate Method GB 11914-89; China Standard Press: Beijing, China, 1989.

45. Du, Y.J.; Hayashi, S.; Liu, S.Y. Experimental study of migration of potassium ion through a two-layer soil system. Environ. Geol. 2005, 48, 1096-1106. [CrossRef]

46. Zhan, T.L.T.; Guan, C.; Xie, H.J.; Chen, Y.M. Vertical migration of leachate pollutants in clayey soils beneath an uncontrolled landfill at Huainan, China: A field and theoretical investigation. Sci. Total Environ. 2014, 470-471, 290-298. [CrossRef] [PubMed]

47. Lohila, A.; Laurila, T.; Tuovinen, J.-P.; Aurela, M.; Hatakka, J.; Thum, T.; Pihlatie, M.; Rinne, J.; Vesala, T. Micrometeorological measurements of methane and carbon dioxide fluxes at a municipal landfill. Environ. Sci. Technol. 2007, 41, 2717-2722. [CrossRef] [PubMed]

48. Johari, A.; Ahmed, S.I.; Hashim, H.; Alkali, H.; Ramli, M. Economic and environmental benefits of landfill gas from municipal solid waste in Malaysia. Renew. Sustain. Energy Rev. 2012, 16, 2907-2912. [CrossRef]

49. Zuberi, M.J.S.; Ali, S.F. Greenhouse effect reduction by recovering energy from waste landfills in Pakistan. Renew. Sustain. Energy Rev. 2015, 44, 117-131. [CrossRef]

50. Liu, Y.; Ni, Z.; Kong, X.; Liu, J. Greenhouse gas emissions from municipal solid waste with a high organic fraction under different management scenarios. J. Clean Prod. 2017, 147, 451-457. [CrossRef]

51. Arafat, H.A.; Jijakli, K.; Ahsan, A. Environmental performance and energy recovery potential of five processes for municipal solid waste treatment. J. Clean Prod. 2015, 105, 233-240. [CrossRef]

52. Al-Jarrah, O.; Abu-Qdais, H. Municipal solid waste landfill siting using intelligent system. Waste Manag. 2006, 26, 299-306. [CrossRef] [PubMed]

53. Chang, N.-B.; Parvathinathan, G.; Breeden, J.B. Combining GIS with fuzzy multicriteria decision-making for landfill siting in a fast-growing urban region. J. Environ. Manag. 2008, 87, 139-153. [CrossRef] [PubMed]

54. Nas, B.; Cay, T.; Iscan, F.; Berktay, A. Selection of MSW landfill site for Konya, Turkey using GIS and multi-criteria evaluation. Environ. Monit. Assess. 2010, 160, 491. [CrossRef] [PubMed]

55. Schreck, P. Environmental impact of uncontrolled waste disposal in mining and industrial areas in Central Germany. Environ. Geol. 1998, 35, 66-72. [CrossRef]

56. Sumathi, V.; Natesan, U.; Sarkar, C. GIS-based approach for optimized siting of municipal solid waste landfill. Waste Manag. 2008, 28, 2146-2160. [CrossRef] [PubMed]

57. Mutluturk, M.; Karaguzel, R. The landfill area quality (LAQ) classification approach and its application in Isparta, Turkey. Environ. Eng. Geosci. 2007, 13, 229-240. [CrossRef]

58. Ekmekçioğlu, M.; Kaya, T.; Kahraman, C. Fuzzy multicriteria disposal method and site selection for municipal solid waste. Waste Manag. 2010, 30, 1729-1736. [CrossRef] [PubMed]

59. Kissida, J.; Beaton, N.K. Landfill park: From eyesore to asset. Civ. Eng. 1991, 61, 49.

60. Misgav, A.; Perl, N.; Avnimelech, Y. Selecting a compatible open space use for a closed landfill site. Landsc. Urban Plan. 2001, 55, 95-111. [CrossRef]

61. Chen, X.; Geng, Y.; Fujita, T. An overview of municipal solid waste management in China. Waste Manag. 2010, 30, 716-724. [CrossRef] [PubMed]

62. Kofoworola, O.F. Recovery and recycling practices in municipal solid waste management in Lagos, Nigeria. Waste Manag. 2007, 27, 1139-1143. [CrossRef] [PubMed]

(C) 2018 by the authors. Licensee MDPI, Basel, Switzerland. This article is an open access article distributed under the terms and conditions of the Creative Commons Attribution (CC BY) license (http://creativecommons.org/licenses/by/4.0/). 